\title{
The Role of Government Climate Policy in an Oil Price Shock: A CGE Simulation Analysis
}

\author{
Saeed Solaymani* \\ Department of Economics \\ Faculty of Social Science \\ Razi University \\ Kermanshah, Iran \\ *Corresponding author
}

\author{
Nora Yusma Bte Mohamed Yusof \\ Department of Finance and Economics \\ College of Business and Accounting \\ Universiti Tenaga Nasional \\ 26700 Muadzam Shah, Pahang Darul Makmur, Malaysia
}

\author{
Arash Yavari \\ Department of Management \\ Faculty of Social Science \\ Payam Noor University \\ Kermanshah Branch, Iran
}

\begin{abstract}
Malaysia has made a pledge to reduce its 2005 GDP emission intensity levels by up to $40 \%$ by 2020 as its contribution to combat climate change. One of the proposed policies to achieve this goal is carbon taxation. We used a computable general equilibrium model to analyse the results of three scenarios - the impact of an oil price shock, the implementing of the climate policy on the Malaysian economy and the oil price rise when the Malaysian climate policy is implemented. We also attempt to assess how these scenarios contribute to the mitigation of rebound effect. The Malaysian climate policy implies a gain on the Malaysian economy of around $0.8 \%$ of GDP. The oil price shock in the presence of the Malaysian climate policy implied an additional gain on it of $0.2 \%$ of GDP (making a total gain of $1 \%$ of GDP), but this is equal to the $1 \%$ of GDP that Malaysia would lose from the oil price rise in the absence of the climate policy. This is implying that the climate policy is a potential economic protection for Malaysia. The climate policy and oil price shock would lead to mitigation of rebound effect in Malaysian economy.
\end{abstract}

Keywords-component; Climate policy; oil prices shock; computable general equilibrium (CGE); Malaysia

\section{INTRODUCTION}

The recent oil price rise has created widespread concern about its impact on world economic growth and income distribution in many countries. Since oil is such a basic component of production, a flotation of oil prices will directly affect the whole economy. During the last few years, the oil market has witnessed substantial price volatility, as well as historically high prices for crude oil. There was an oil price shock between 2004 and 2008, in which the pricing references such as Brent and West Texas Intermediate crude increased from \$30 US a barrel to more than \$100 US a barrel. Besides, another shock in this market has happened recently where the crude oil prices have increased from \$75 US a barrel in early 2010 to more than \$100 US a barrel in the middle of 2011.
Malaysia addresses the issues of climate change and energy security through its climate and energy policies, which commits Malaysia to reducing GDP emission intensity by $40 \%$ in 2020 compared with the 2005 levels. Empirical studies showed that significant decreases in greenhouse gas (GHG) emissions can reduce the risks of large damage from climate change [11]. Malaysia, by meeting this goal as one of the greatest GHG pollutants in the Southeast Asia region, can encourage other neighborhood countries to reduce their GHG emissions.

In this study, Malaysia is used as a case study and a computable general equilibrium (CGE) approach is adopted as an analytical framework to explore whether implementing a climate policy makes Malaysia more resilient to the macroeconomic consequences of an oil price shock. While the majority of studies on oil price shocks for the Malaysian economy employ econometric and partial equilibrium methods, there are a few studies that have comprehensively investigated this phenomenon in Malaysia without any focus on climate policies $[18,13]$. Therefore, this study can contribute towards the literature.

\section{LITERATURE REVIEW}

While the impact of a rise in oil prices in the developed and oil exporter countries could in general be positive because of the terms-of-trade improvement, energy-intensive industries could be adversely affected by the same shock $[8,4]$. Indeed, the aggregate price changes due to the high oil prices dissipate largely over time at the aggregate levels and the aggregate level of prices. by increase in the level of technological advances decrease [5].

Dissou [4] revealed that the extent of the negative impact on the economy depends on the export intensity of the energyintensive sectors, and non-oil-producing sectors could be affected by an appreciation of the real exchange rate that could eventually shift resources from the affected sectors to the 
booming sectors. In contrast, for net oil-exporter, open and developing economies, the impact of high oil prices depends on how they interact with the consumer and investor confidence. For example, the direct impact of high oil prices on both Indonesia and Malaysia is positive (this is similar to the findings of Saari et al. [12]) and in the long run, they also lose out [1]. In contrast, many studies showed that an oil price shock, in the developing and developed economies, affects most the industrial sector [2, 6, 7]. Manap and Kassim [10] indicated that an oil price shock, as a positive supply shock, increases output, and negative supply shocks contract output and increase price levels in this country. Furthermore, supply shocks have a greater impact on output than demand shocks in the long run.

On the other hand, a few studies address the interactions between climate policy and oil prices. Maisonnave et al. [9], by employing the GEM-E3 computable general equilibrium model, found that the unilateral climate policy can protect the EU economies from high oil prices. Van Ruijven and van Vuuren [15] using the global energy model TIMER found that without a climate policy, high hydrocarbon prices drive electricity production from natural gas to coal which leads to increased emissions of $\mathrm{CO}_{2}$. With a climate policy, high hydrocarbon prices cause a shift in electricity production from a dominant position of natural gas with carbon capture and sequestration (CCS) to coal-with-CCS, nuclear and wind. Vielle and Viguier [17], using a computable general equilibrium model, suggested that high oil prices cannot serve as substitutes for effective climate policies. Torvanger et al. [14] believed that the stringency of policies needed to meet a climate target is influenced by uncertain oil prices because price changes cause emission changes, making the robustness of climate policy instruments important.

Verbruggen and Al-Marchohi [16] argued that oil production and consumption are the most necessary sources for controlling climate change. Peak-oil belief could stimulate a passive approach in climate policies by suggesting that reducing carbon dioxide emissions can decline oil production and consumption.

Therefore, implementing climate policies in order to reduce GHG emissions and the negative impact of an oil price shock on the whole of the economy is necessary for policy makers. Malaysia, as a small open and net oil-exporter economy, is not exempted from that.

\section{Methodology}

To estimate the economic and climate effects of an increase in global oil prices and climate policy, this study uses a computable general equilibrium (CGE) model for Malaysia. Since CGE models are useful and powerful models for analyzing the effects of shocks and polices on aggregate and sectoral levels, this study attempt to employ these models.

The theoretical structure of the model closely follows the Solaymani and Kari [13] model

\section{A. Data and Closures}

The main database of this study is 2005 Malaysia InputOutput table and 2005 Statistical Yearbook of Malaysia. In the closure part of the model, the government consumption as well as its transfer to institutions is fixed. The market for foreign exchange is cleared by fluctuations in the exchange rate, whereas the current account is fixed. Three labor types and capital supply are exogenously fixed. Markets for three labor categories and capital are cleared by endogenous factor prices. Since the model is static and there is no any change in factor supply, the results of the model must be interpreted as shortrun results.

\section{B. Description of the Simulations}

Our scenarios assume that Malaysia implements climate policies. Three scenarios are investigated: a rise in the oil price alone (OP), the introduction of climate policy (CP) and both together $(\mathrm{OP}+\mathrm{CP})$. For the oil price shock case (OP), we have considered a scenario with oil prices rising during 2004-2005. In 2005 compared to 2004, the price of crude oil increased significantly in the world market. Therefore, in this study, the world prices of oil show a permanent increase of $30 \%$, based on the rise in the world market prices of crude oil in 2005, in comparison with 2004.

This increase consists of an immediate 30\% rise in world prices (exports as well as imports) of oil products (Crude oil and Refined Petroleum) from the reference value to a new value that remains henceforth constant.

The second scenario (CP) represents a climate policy for Malaysia. This involves a commitment to decrease $\mathrm{CO}_{2}$ emission by $5 \%$ in the short-run.

The model implements a carbon tax of 18 USD per ton of carbon on fossil fuels to achieve 5\% reduction in carbon emission. This leads to an increase in the production prices (depending on the emission intensity of the production sector).

The third scenario $(\mathrm{OP}+\mathrm{CP})$, combines the oil price rise (OP) scenario and the climate policy (CP) scenario. The purpose of this scenario is to investigate whether climate policy results in a gain or additional loss of GDP if there are high oil prices. This involves comparing the differences between the oil price shock (OP) and the combined scenario $(\mathrm{OP}+\mathrm{CP})$, versus the differences between the baseline situation and climate policy. Alternatively, one could ask whether climate policy offers protection against a high oil price. This involves comparing the differences between the climate policy (CP) and the combined scenario $(\mathrm{OP}+\mathrm{CP})$ versus the differences between the baseline situation and oil price shock.

In order to provide an intuitive explanation of the results, the study discusses aggregate and sectoral impact separately and this discussion focus on the main transmission channels which play a prominent role in the economy. It is necessary to emphasize that the results presented in this study are the results of counterfactual simulations, which, ceteris paribus, indicate the impact on economic activities of the considered scenarios. 


\section{Simulation RESULtS}

\section{A. Aggregate Impact}

Table 1 clearly shows that the oil price rise is less costly when a climate policy is in place. An oil price shock without climate policy would lead to a $0.4 \%$ loss of real GDP. With a climate policy in place, the same oil price shock gains real GDP by $0.2 \%$. In this respect, the results demonstrate that the climate policy can offer potential protection against an oil price rise.

An alternative way of viewing these results is to look at the cost of implementing a climate policy. As previously shown, without oil price rise, implementing a climate policy would lead to a $0.2 \%$ gain of GDP. However, if oil prices increase, the Malaysian economy by finding alternative energies can substitute away from oil to some extent, and therefore implementing, a climate policy causes a benefit of $0.1 \%$ of GDP.

TABLE I. RESPONSE OF REAL GDP TO DIFFERENT SCENARIOS SOURCE: SIMULATION RESULTS

\begin{tabular}{c|ccc}
\hline \multirow{2}{*}{} & \multicolumn{3}{|c}{ \% change with respect to the baseline values } \\
\cline { 2 - 4 } & \multicolumn{2}{|c}{ No oil price shock Oil price shock } & $\begin{array}{c}\text { Gain of oil price } \\
\text { rise }\end{array}$ \\
\hline No climate policy & Baseline situation & -0.39 & -0.39 \\
Climate policy & 0.17 & -0.34 & -0.17 \\
Gain of climate policy & 0.17 & -0.73 & ---- \\
\hline
\end{tabular}

Note: Positive and negative values are gains and losses from the policy, respectively.

Household welfare is calculated from the consumers' utility function, which takes account of the utility derived from consumption of both goods and services. The oil price shock would decrease household welfare in all categories due to the negative impact on consumption (Table 2). As declines in household consumption due to the shock are equal to declines in their incomes, households react in the short-run according to their current income, not according to their permanent income. Therefore, their welfare falls and settles at a lower utility level. Overall, the welfare of rural and urban households' decrease, as showed by the negative welfare change of $1.8 \%$ and $2.6 \%$ as compared with the base run value. The climate policy (CP) would induce $7.9 \%$ and $12.2 \%$ rises in rural and urban welfare, respectively. This pattern accrued in the combined scenario also.

TABLE II. IMPACTS OF DIFFERENT SCENARIOS ON CONSUMPTION AND WELFARE OF HOUSEHOLDS

\begin{tabular}{l|ccc}
\hline \multirow{2}{*}{ Variables } & \multicolumn{4}{|c}{ \% change with respect to the baseline values } \\
\cline { 2 - 4 } & \multicolumn{1}{c}{ OP } & CP & OP + CP \\
\hline Consumption & & & \\
$\quad$ Rural & -1.67 & 7.17 & 5.59 \\
Urban & -1.48 & 11.24 & 9.87 \\
& & & \\
Welfare & & & \\
$\quad$ Rural & -1.82 & 7.87 & 6.13 \\
Urban & -1.61 & 12.23 & 10.73 \\
& & & \\
\hline
\end{tabular}

It can be concluded that, the magnitudes of the impact on most of the variables reported so far are small, except for investment and welfare variables. These findings are in line with the magnitude of the high shock, and are not significantly different from the ones obtained in other models. For example, Yeah [18], using a seven-sector computable general equilibrium model, found that a $30 \%$ increase in oil prices has a positive impact (about $0.3 \%$ ) on the Malaysian GDP in the short run. Moreover, the results of Solaymani and Kari [13] study are also similar to the current study. The magnitude of the aggregate impact of the current study in comparison with other studies may be due to differences in shock type, size of the shocks and differences in sectoral adjustments. Contrary to other CGE studies, the increase in world prices of energy carriers does not affect all sectors equally.

\section{B. Sectoral Impact}

Analysing the static impact of the three scenarios on sectoral variables of the Malaysian economy will give a comprehensive insight into these effects. The impacts on the main relevant sectoral variables are presented in Table 3 .

On the supply side of the economy, oil price rises will cause some resource reallocation effects, with labour moving from other sectors to oil-producing sectors. As shown in Table 5 , employment and gross output increase in the crude oil and natural gas sectors as well as the petroleum products sector, while falling in other sectors. Therefore, it increases incentives to invest in oil-producing sectors. Thus, resources shift toward these sectors and lead to significant increases in their output. In contrast, in the other sectors, the increase in energy costs and decrease in their sales (or domestic demand) reduces the firms' incentives for new investment. Output of the petroleum refinery, however, increases by $5.5 \%$. This increase can be attributed to its higher profitability, vis-à-vis, the other sectors, especially the services sectors, which are adversely affected by the oil shock.

TABLE III. CHANGE IN SECTORAL OUTPUT AND EMPLOYMENT

\begin{tabular}{l|ccc|ccc}
\hline \multirow{2}{*}{\multicolumn{1}{c|}{ Sectors }} & \multicolumn{5}{c}{ Percentage change from base-run } \\
\cline { 2 - 7 } & \multicolumn{3}{|c}{ Gross output } & \multicolumn{3}{c}{ Employment } \\
\cline { 2 - 7 } & OP & CP & OP + CP & OP & CP & OP + CP \\
\hline Agricultural & -0.17 & 0.97 & 0.84 & -0.13 & 1.04 & 0.98 \\
Forestry \& logging & -0.28 & 0.19 & -0.17 & -0.54 & 0.41 & -0.28 \\
Crude Oil & 0.52 & -0.05 & 0.45 & 0.39 & -0.03 & 0.34 \\
Natural Gas & 0.05 & -0.05 & -0.03 & 0.03 & -0.03 & -0.01 \\
Mining & -0.98 & -0.46 & -1.66 & -0.03 & -0.02 & -0.06 \\
Food processing & -0.49 & 2.17 & 1.84 & -0.13 & 0.70 & 0.61 \\
Textiles & -0.57 & 0.72 & -0.05 & -0.10 & 0.14 & 0.01 \\
Petroleum refinery & 5.54 & 3.52 & 9.53 & 4.22 & 2.49 & 8.37 \\
Chemical, rubber, plastic & -1.80 & 0.59 & -1.25 & -0.59 & 0.20 & -0.40 \\
Cement \& non-metals & -2.27 & -1.32 & -4.02 & -0.38 & -0.24 & -0.69 \\
Iron \& steel products & -1.51 & -0.27 & -2.07 & -0.32 & -0.06 & -0.43 \\
Manufacturing & -0.59 & 0.97 & 0.29 & -0.17 & 0.29 & 0.10 \\
Electricity & -0.92 & 2.25 & 1.72 & -0.14 & 0.40 & 0.30 \\
Gas & -0.92 & 2.25 & 1.72 & -0.14 & 0.40 & 0.30 \\
Trade works, wholesale & -0.28 & -4.58 & -5.60 & -0.34 & -5.98 & -7.20 \\
Land transport & -0.17 & 0.06 & -0.34 & 0.00 & 0.00 & -0.02 \\
Water transport & -1.24 & -2.41 & -4.17 & -0.17 & -0.35 & -0.58 \\
Air transport & -2.64 & 1.30 & -1.54 & -0.13 & 0.06 & -0.08 \\
Other transport services & -0.39 & -0.17 & -0.73 & -0.04 & -0.02 & -0.09 \\
Communication & -0.17 & 2.08 & 2.09 & -0.04 & 0.51 & 0.52 \\
Financial Institution & -0.49 & 2.13 & 1.79 & -0.13 & 0.59 & 0.50 \\
Other Services & -0.27 & 3.20 & 3.22 & -0.06 & 0.77 & 0.79 \\
\hline
\end{tabular}

Source: Simulation results 
The climate policy scenario also leads to the reallocation of resources and change in gross output of sectors. For example, the production factors shift from crude oil, natural gas, cement and iron and steel sectors to services sectors. Therefore, the gross output of oil-intensive sectors except the petroleum sector decreases, while it increases in services sectors. The petroleum refinery sector experienced the highest increase in the level of employment and output, followed by other services sector. On the other hand, the trade works, which includes wholesales and retails, experienced the greatest decrease in its employment and output.

In the combined scenario, the petroleum refinery followed by the other services sectors experienced the highest rise in their employment and output. However, the trade works, followed by water transport sectors, are the main losers of this policy in terms of employment and output.

Empirical research has shown that non-oil-producing sectors are affected, not only by the resource shift towards oil sectors, but also by an increase in their production cost due to the rise in oil prices [4]. Therefore, their exports decrease more if the export prices of oil sectors alone increase.

Increase in a total output of oil-intensive sectors due to the climate policy would raise the exports of these sectors. The climate policy also leads to decrease in the imports of these sectors. The petroleum refinery, followed by crude oil and natural gas sectors, experienced the greatest rise in their exports, while the electricity, gas and financial sectors experienced the highest rise in their imports. The effects of the combined scenario on both exports and imports are mixed. The exports of the majority of service sectors decreased while their imports increased. However, although the exports of most of the industries increased, the majority of services sectors experienced a decrease in their imports. The petroleum refinery, followed by crude oil and other services sectors experienced the highest increase in their exports, while the trade works, followed by these sectors have the lowest imports among other sectors.

\section{CONCLUSION}

In this study, we investigated the potential effects of three scenarios on the Malaysian economy. The first is a 30\% rise in the world prices of oil products. The second is implementing a climate policy in order to reduce $5 \%$ of $\mathrm{CO}_{2}$ emission in this country and the third scenario is imposing both the oil price shock and the climate policy on this economy together. We used a multi-sector computable general equilibrium model that makes it possible to trace the impact of these scenarios on the economy.

The simulation results suggest that the main benefit of the climate policy is offsetting the negative effects of the oil price shock. It protects the economy against the macroeconomic consequences of an oil price shock. In terms of magnitude, the scenario where Malaysia reduces $\mathrm{CO}_{2}$ emissions by $5 \%$ would lead to a rise in real GDP of $0.2 \%$. For the oil price shock, the loss of GDP without implementing a climate policy is about $0.4 \%$, and is $0.3 \%$ when it implemented. In other words, a climate policy not only does not increase the loss of GDP but also it reduces the GDP loss of a Malaysia economy from $0.4 \%$ to a $0.2 \%$ gain. This can be interpreted as the extent of the protection offered by the climate policy against the oil price shock.

The oil price shock would decrease the income, consumption and welfare of all households groups while implementing a climate policy without and with an oil price shock leads to a welfare gain for rural and urban households. The oil price shock drops the Malaysian trade follows, whereas the climate policy stimulates it. The combined scenario also leads to a gain for Malaysian trade.

\section{REFERENCES}

[1] Abeysinghe, T. Estimation of direct and indirect impact of oil price on growth. Economics Letters 2001; 73: 147-153

[2] Ali-Ahmed, H.J., Mokhtarul, I.K.M.W. Role of oil price shocks on macroeconomic activities: An SVAR approach to the Malaysian economy and monetary responses. Energy Policy 2011; 39: 8062-8069

[3] Chattopadhyay, D., Majumdar, S. Impacts of oil price shock on carbon emissions in India: an econometric analysis. Energy Sources 1996; 18: 6 , 711-726

[4] Dissou, Y. Oil price shocks: Sectoral and dynamic adjustments in a small-open developed and oil-exporting economy. Energy Policy 2010; 38: $562-572$

[5] Doroodian, K., Boyd, R. The linkage between oil price shocks and economic growth with inflation in the presence of technological advances: a CGE model. Energy Policy 2003; 31: 989-1006

[6] Jbir, R., Zouari-Ghorbel, S. Recent oil price shock and Tunisian economy. Energy Policy 2009; 37: 1041-1051

[7] Kerschner, C., Hubacek, K. Assessing the suitability of input-output analysis for enhancing our understanding of potential economic effects of Peak Oil. Energy 2009; 34: 284-290

[8] Lee, K., Ni, S. On the dynamic effects of oil price shocks: a study using industry level data. Journal of Monetary Economics 2002; 49: 823-852

[9] Maisonnave, H., Pycroft, J. Saveyn, B., Ciscar, J-C. Does climate policy make the EU economy more resilient to oil price rises? A CGE analysis. Energy Policy 2012; 47: 172-179

[10] Manap, T.A.A., Kassim, S.H. Sources of macroeconomic fluctuations in Malaysia: an empirical test of the Keynesian model. The Asia Pacific Journal of Economics \& Business 2007; 58-77: 80-81.

[11] Mastrandrea, M.D., Schneider, S.H. Probabilistic integrated assessment of "dangerous" climate change. Science 2004; 304 (5670): 571-575. American Association for the Advancement of Science.

[12] Saari, M.Y., Puasa, A.F., Hassan, K.H. The Impact of World Crude Oil Price Changes on the Malaysian Economy: an Input-Output Analysis. Malaysian Journal of Economic Studies 2007; 1-12

[13] Solaymani, S. Kari, F., 2013. Environmental and economic effects of high petroleum prices on transport sector. Energy 60, 435-441.

[14] Torvanger, A., Kallbekken, S., Tollefsen, P. Oil price scenarios and climate policy: welfare effects of including transportation in the EU emissions trading system. Mitig Adapt Strateg Glob Change 2012; 17: 753-768

[15] van Ruijven, B., van Vuuren, D.P. Oil and natural gas prices and greenhouse gas emission mitigation. Energy Policy 2009; 37: 4797-4808

[16] Verbruggen, A., Al-Marchohi, M. Views on peak oil and its relation to climate change policy. Energy Policy 2010; 38: 5572-5581

[17] Vielle, M., Viguier, L. On the climate change effects of high oil prices. Energy Policy 2007; 35: 844-849

[18] Yeah, K.L. Computable general equilibrium analysis of external and policy shocks on the Malaysian agricultural sector. PhD dissertation, University of Hawaii 1992. 